\title{
Art in public space as a tool of social inclusion
}

\author{
Agnieszka Chęć-Małyszek \\ a.chec-malyszek@pollub.pl \\ Department of Architecture, Urban and Spatial Planning, \\ Faculty of Civil Engineering and Architecture, University of Lublin
}

\begin{abstract}
Summary: What would art be if it were not viewed by people and could not influence the environment? Without the audience and spectators, it would be nothing, therefore it should be accessible and "graspable" for everyone. Elements of art placed in urban space have always enriched the "urban tissue", providing man with many positive experiences. They enter into a dialogue with the city's inhabitants, contribute to the growth of the its potential, and at the same time, influence all the senses of human beings. Art in urban space influences the perception of its audience, encourages dialogue, and creates a platform for better understanding of people's needs and their functioning in the public sphere. It also plays an important role in the process of socialisation of the society, regardless of where it is exhibited.
\end{abstract}

Keywords: art, public space, integration, social inclusion, art in public space

\section{Introduction}

Public space, in which people live every day, has a huge impact on people. Nowadays, instead of galleries, art more and more often ends up in streets, squares, or promenades. Designers and architects, in order to reach their audiences, more and more often create unique and vibrant meeting points, complemented by elements of art. Public space is more and more frequently treated as an area for social exchange, where art is one of the ways of speaking out. Elements of art situated in urban spaces no longer surprise anyone, but constitute an integral part of the city's unique structure.

According to some theoreticians, urban space has lost its importance ${ }^{1}$, and yet, everything indicates that this is not the case. Just the opposite, it has gained new momentum, becoming an excellent tool for building closer social ties.

According to Joseph Rykwert, a modern city, so diverse and full of different attitudes and needs, must have many faces and be multisensory. ${ }^{2}$ Art creates its dimension through colour, texture, material, sound, or smell. It creates a symbolic image of a given place, responds to the needs of citizens, and helps to make the public identify with the 'urban tissue'. It perfectly decorates and beautifies a given area, triggering unusual aesthetic experiences in man.

Placing works of art in public spaces began as early as in the 1960s, when there was a clear increase in investors' interest in the humanization of urban environments. Contemporary public space in cities has been largely dominated by modern technological achievements, contributing to the creation of a structure with a dehumanized image. Elements of art placed in urban space have a positive impact, which is why contemporary artists use all forms available to influence and attract audiences. Nowadays, a bigger attention is being paid to well-designed, human-friendly urban spaces, where designers and city authorities are doing their utmost to make them ideal meeting places for socializing. 
Camillo Sitte perceived the city and the surrounding space as a work of art, the phenomenon of which consists in skillfully composing a man-friendly urban space. Introducing elements of art into the city space contributes to its attractiveness, raises the standard of living, and brings residents closer together. In order to meet citizens' needs in an appropriate way, it is important to treat the city as a complex system comparable to a living organism ${ }^{3}$, where art is a key element contributing to the creation of a unique urban space.

This paper aims to show the importance of art in building social relations and the role of artistic media that are displayed in urban space in the process of social inclusion.

\section{Art in urban space}

Art is undoubtedly a social phenomenon, due to how it is created and what it is used for. Its social character concerns on the one hand the origin of its products, and on the other the impact on society. Stanisław Ossowski distinguished three basic functions of art: cataractic, bond-forming, and transformational, the sum of which contributes to the upbringing of society in the "spirit" of art. The first of them is closely related to the direct experience of artistic reality ("here and now"), which influences emotional and intellectual stimulation. The bond-forming function, in turn, manifests itself in the development of social relations, going beyond what is "here and now", supporting the process of shaping the social functions of people and their ability to communicate with each other. For this reason, it can be a factor that harmonizes social relations and counteracts conflicts. Art protects against the stiffening of the worldview, encourages independence in its assessment, and shapes the creative attitude towards reality both for its creators and recipients.

Marian Golka ${ }^{4}$, devotes a lot of attention to the social functions of art today, as he attributes two of its most important functions, such as modelling social values and social ties. ${ }^{5} \mathrm{He}$ also distinguished co-existing functions, such as aesthetic, hedonistic, therapeutic, expressive, communicative, magical, ideological, educational, cognitive or economic, which prove "that art is an aspect of social life and not something separate from it." 6

Artists continue to go beyond the walls of galleries and other artistic institutions using public space to expose their works. This allows them to communicate with different social groups through artistic means.

Cher Krause Knight believed that the public character of art depended primarily on its relations with the viewers, the influence it exerts on them, and the influence they exert on it. Therefore, it is perceived primarily through the prism of communicative, interpretive and assimilating functions it has on the audience.

Art in the public space has always accompanied man, as it is created by people and for people. It can be found in Greek statues, triumphal arches, or ancient Rome, where its individual elements were placed in temples or on city squares. It functions in everyday life as a sculpture, statue, installation or a canvas which are made of various materials such as stone, metal, wood and glass, or as an element of everyday use. Public art "is shaped by the artist's intentions, the requirements and wishes of investors, the urban context and the demands of the collective addressee with aesthetic needs that are difficult to identify". ${ }^{7}$

Confrontation with the viewer is a breakthrough moment for a work of art, as it tells a certain story of the presented work. Some theorists, as a category of art in public space, distinguish public art determined by the relations between public art and public space ${ }_{1}^{8}$ integrating the existing historical, social, architectural and urban reality. Art becomes public because of the problems it raises. It is something unchangeable that requires the involvement of the creator and the viewer. It often serves to commemorate important figures and events, including painful and traumatic ones. It touches upon important problems of social exclusion, sexual orientation, and numerous diseases of civilization. Its main task is, first of all, to instill desired behaviours, ideologies, and social attitudes towards the surrounding reality. It helps to build a social urban identity, being an element of identification, which is often closely linked to the area and the people living there. This kind of art fits into 
the existing context of the place. The sculpture of Monika Sosnowska "Krata" in the Bródno Sculpture Park can serve as an example. The material from which it was made (reinforcing bars) resembles metal bars with which the inhabitants of the blocks protected the ground floors of their houses, playgrounds, or service points.

Art in the public space also has the function of promoting a given place, becoming an easily identified sign that attracts tourists. A large part of it often serves as a signpost, which helps not only to find a given place on the map, but also to assign the work to a given city. An example of this is the Stravinsky Fountain at the Centre Pompidou in Paris, which is part of the identification of a given place.

Since the city is a natural human environment, the care for the aesthetic qualities of buildings, streets and squares, has become the main task of architects and urban planners. Since time immemorial, art has served man, evoking both positive and negative emotions. Parks, gardens, alleys and promenades are perfect places to present art that brings people closer together, allowing them to stop for a moment.

Nowadays, art is becoming an element more and more often used by architects, who create a new, humanizing image of the city. Introducing elements of art into the city space improves the quality of life of its inhabitants, presenting its beauty, sublimity and uniqueness. Introducing elements of art into the urban tissue increases the city's potential and maked the individual identify with the given place, building closer social bonds.

Elements of art increasingly appear on the occasion of contemporary events promoting cities and entire regions, such as those created as part of the European Capital of Culture Days. Saturation of public space with art can also be an important element of urban development strategies, which can be observed on the example of the city of Lublin. Introducing elements of art influences the shaping of the cultural landscape of the city, at the same time favouring its revitalization and reconstruction. The contribution of muralistic art to the renovation of residential districts can be presented on the example of Lublin or Łódź. (Figures 1,2,3) The murals, using symbolic elements, often raise important social issues and thus differentiate the architectural urban tissue. They are critical of the political situation of a community and make the building "raise its voice" in public debate. Painted murals often draw attention to a social problem, being a typical articulation or manifestation activity. An equally important element is their type and context oriented towards the social change caused by entering the public space. The processes of social exclusivity and inclusion, which are the area of artistic intervention and cooperation, put the creators in the face of the necessity to change their actions in a way that eliminates barriers to social participation. Frequently, artistic activities carried out in public space become icons that permanently enter the pop culture circuit, becoming objects identified with a given place.

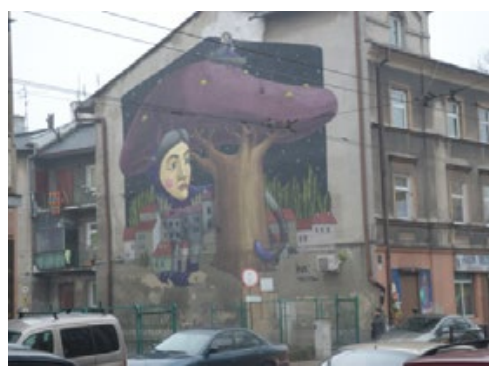

Fig. 1. The mural located on Lubartowska street in Lublin, 2017, author's photo

Mural znajdujący się przy ul. Lubartowskiej w Lublinie, 2017, fot. autora

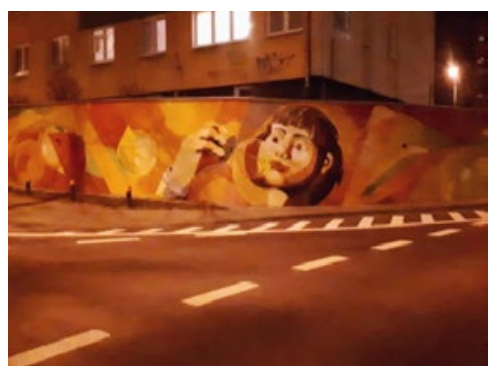

Fig. 2. The mural located on the wall in Kalinowszczyzna estate in Lublin, 2017, author's photo

Mural na murze os. Kalinowszczyzna Lublin, 2018, fot. autora

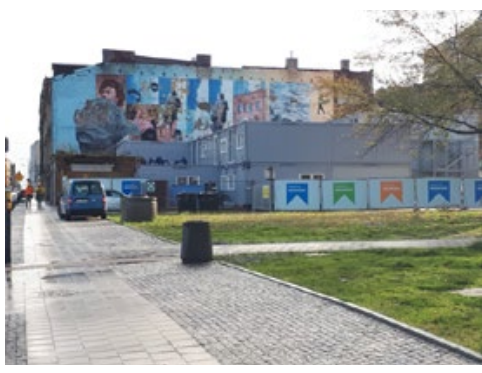

Fig. 3. The mural located on the wall in Łódź, 2017, author's photo

Mural na jednej ze ścian w Łódzi, 2017, fot. autora

In the 1960s for the first time appeared postulates that art should be "released" for the benefit of the public space outside the gallery exhibition, close to the random viewer and the local community. The art of those times became a political and social background, "fighting for" civil rights of minority groups, racial groups, women, or people excluded and unjustly treated.

One of the first artistic manifestations of rebellion and social discontent in the modern times was the extensive activity of large-format wall paintings, called murals. The current of those times was called social art, being one of the early forms of art in public space. The going out of artists with their work outside the galleries, contributed to shaping the conviction that art can fulfil many social and socializing functions. 
The art of the 1960s presented in the form of numerous murals, sculptures, and mosaics was created by the community, and their performer was the artist himself. Elements of art began "flooding" squares, parks, backyards or housing estates, presenting the real problems of a given community, and in particular the group of excluded people.

The art of the 1980s presented in public space was a kind of barometer of social moods, which was not always accepted by its recipients, but was able to arouse emotions. It counteracted visual monotony by improving the aesthetic quality of stations, airports, railways, parks, and squares.

Nowadays, thanks to introducing elements of art into the urban tank, given places do not become "soulless" and associated with modern and "inaccessible" architectural and urban space. Characteristic signs of art give a visual identity to a given place, as well as aestheticize and beautify the space, satisfying the human need to commune with beauty. Elements of art are an excellent landmark. They are also used on hospitals and other public buildings.

Art in urban space takes on various forms, where on the one hand it creates "street art", in the form of multi-format murals, and on the other hand, it presents full-size installations that enliven the "urban tissue". Art in different forms brings peace and serenity, to many people, increasing their sense of satisfaction with their everyday life and teaching them the openness to others. At present, elements of art in urban space can be encountered in many places in Poland or abroad. (Fig. 4,5,6) Thanks to the spread of art in urban space, it is no longer necessary to visit museums to admire it, but it is enough to keep one's eyes wide open and discover it in everyday life.

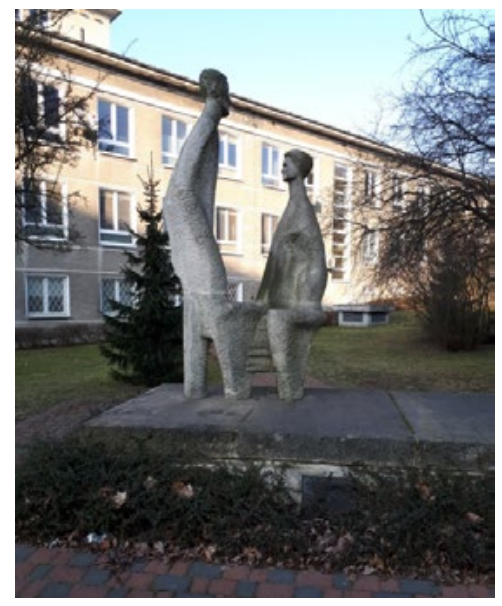

Fig. 4. The sculpture located in front of the Samodzielny Szpital Kliniczny on Jaczewskiego street in Lublin, 2017, author's photo

Rzeźba znajdująca się przed budynkiem Samodzielnego Szpitala Klinicznego przy ul. Jaczewskiego w Lublinie, 2018, fot. autora

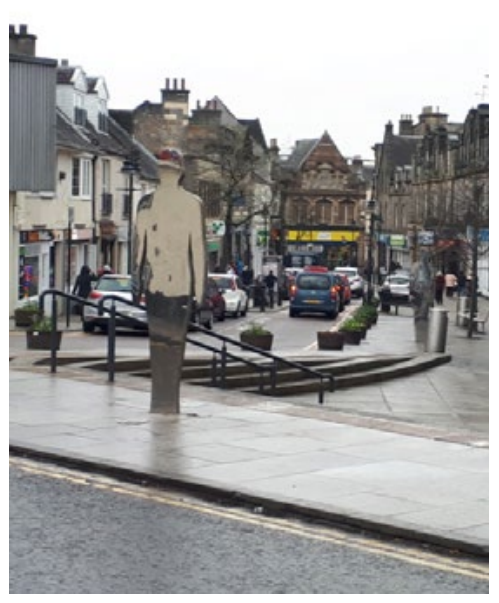

Fig. 5. The sculpture located in a predestrian way in a small town Alloa in Scotland, 2018, author's photo

Rzeźba znajdująca się na deptaku niewielkiego miasteczka Alloa w Szkocji, 2018, fot. autora

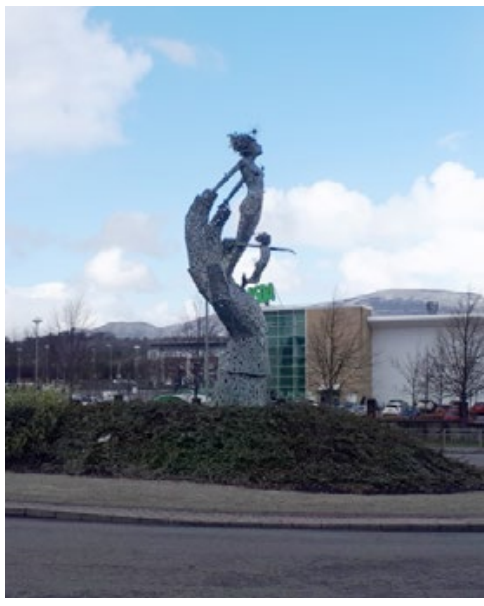

Fig. 6. The sculpture on a hill, Glasgow, Alloa, Scotland, 2018, author's photo

Rzeźba znajdująca na rondzie niewielkiego miasteczka Alloa w Szkocji, 2018, fot. autora

Plazas, alleys, promenades and squares create places conducive to human interaction, where art in space creates a centre of understanding, provoking the exchange of views and the expression of social opinions. A creative use of urban space in a simple way can make it unrecognizable, giving a distinctive character to even the most inconspicuous places. 


\section{Art and integration (inclusion)}

In literature, there are many views on integrative upbringing through art. Irena Wojnar believes that it engages the whole personality of the viewer, influences its comprehensive development, and maintains the desired balance between modelling the mind and the development of feelings and imagination. ${ }^{9}$

Herbert Read considered art to be an important element that shapes an integral human being, develops mental and social skills and the ability to establish social contacts. ${ }^{10}$ The above statements confirm the immense power and values of art, which comprehensively shapes people in every sphere of intellectual experience, as well as their moral and social attitudes.

The concept of integration (inclusion) can be explained as a process of integration into a certain, essential part of the society, usually of a diverse and minority group of people that is characterised by mutual respect and has identical conditions for maximum development. ${ }^{11}$

The concept of social inclusion is a relatively new form of social integration; therefore solutions are still being sought that could contribute to the building of social identity. One such initiative includes art exhibited in urban space, which favours meetings and exchange of views, thus integrating society and creating a more tolerant and cohesive community.

The integration process brings benefits for the entire local community, contributing to the acquisition of cultural, normative, communicative and functional skills and abilities. It develops in people the ability to communicate in a group, establishes interpersonal ties, and teaches how to act together and build specific behaviors. ${ }^{12}$ The main objective of social integration is to create in a natural social environment conditions for development, learning, work, and spending free time for all citizens.

Art in the perceptual dimension carries an enormous power of educational impact, as it teaches sensitivity and tolerance towards others. It promotes communication, allows for the elimination of verbal and sensory experiences, deepening relations among members of society. This includes various artistic creations in the form of sculptures, paintings or installations, as well as all cultural events that encourage social gatherings. In each type of artistic activity one can see something separate and original, something that was shaped by the artist's personal experiences.

A very important part of the integration process is communication, which is one of the fundamental elements necessary for social inclusion. Introducing elements of art into the public space plays an important role in the process of socialization of society, being an important link conducive to meetings and exchange of views of different social strata.

Art, both directly and indirectly, affects the audience and plays a major role in the integration process. An important issue raised in this study is recognizing the mechanism of this impact as well as understanding the integrative function of art and its artistic means in their richness and complexity. The influence that individual fields of art exert on man in the process of integration, differ in a fundamental way and have a different impact.

Art directed towards viewers, often strongly influences their emotional and rational sphere. A given work of art in its integrative function may refer to the emotions or the reason of the recipient. Art often operates on the basis of emotions and stereotypes, which determine the power, duration and impact it has on the viewer. Reception or participation in various artistic activities often combines free time and entertainment, which allows breaking away from everyday duties and escaping into one's dreams. The basic factor determining the phenomenon of integration, is knowledge and a deeply integrated system of values, both of which contribute to its deepening and increasing the durability of the social ties that have arisen.

From the historical point of view, integration or assimilation with art and through art is usually one-way. Each type of art has its own specificity, which is determined by the "artistic creation" and influences the formulated conclusions. The above remarks show how many issues are related to the integrative function of art and how complex and incomprehensible this problem is.

9 I. Wojnar, Teoria wychowania estetycznego - zarys problematyki. Państwowe Wydawnictwo Naukowe, Warszawa 1980, s. 12

10 H. Read, Wychowanie przez sztukę., J. Bielecki, Osobowość młodzieży niepetnosprawnej z zaburzeniami wzroku, słuchu, ruchu i mowy. Pallotinum, Warszawa 1990, s. 178-182

11 https://pl.wikipedia.org/wiki/Integracja_spo\%C5\%82eczna. [dostęp: 19.12. 2016]

12 J. Zabłocki: Integracja szansą wychowania nowego pokolenia. Wydawnictwo Naukowe NOVUM, Płock 2002, s. 76 


\section{Art as a social dialogue}

Elements of art in the form of monuments, sculptures, fountains, or architectural decorations have always enriched public space while commenting on social life. Introducing elements of art into the urban tissue provides many positive aesthetic sensations, which contribute to the growth of the city's potential by creating a "flexible creation" that fits perfectly into every type of urban space, while at the same time, affecting all the senses of human beings. ${ }^{13}$

According to llya Kabakova, audience-oriented art is one whose central point of interest is the recipient not the work of art itself, which means that the artist creating a given piece of work concentrates mainly on his or her audience. The artist publicly takes on the role of a medium: "he/she does not try to dominate or terrorize places, but wants to listen to them, to tune in to the voices, sounds and music that fill this particular place". ${ }^{14}$

Introducing elements of art into urban space "humanizes" it, thanks to which it becomes more friendly and accessible to all residents. The main task of art is the subconscious change in man's attitudes or ideas. By exhibiting the work in the urban space, the artist creates an opportunity to change attitudes in people, at the same time providing them with the means they need. The transformative role of art equips people with intellectual and practical tools for change. It is often recognized as a form of civic activity that requires a redefinition of the idea that artistic, social, and civic thinking are separate, as well as the recognition that each individual is capable of creative thinking and taking actions in his or her environment.

Generally speaking, art allows people to express their negative and positive opinions, helping to change their current situation. Participation in cultural and artistic events allows a free exchange of views and an important integration with a community of similar interests and views. In a creative way, it supports cognitive processes and has a positive impact on the viewer and his/her surroundings.

The aim of every artistic creation is to show a certain truth. Art "speaks" for itself, materializes the value of truth and beauty, and allows to enter the world of the artist's experiences. It is particularly important for people with disabilities, for whom it is one of the most important channels of communication with the outside world. This is because "a work of art takes us by the hand and leads to what is hidden deeper, to the essential truth. It shows us that truth with its entire itself. In a nutshell, it shows the wonderful synthesis, which allows the viewer to reverie." ${ }^{15}$

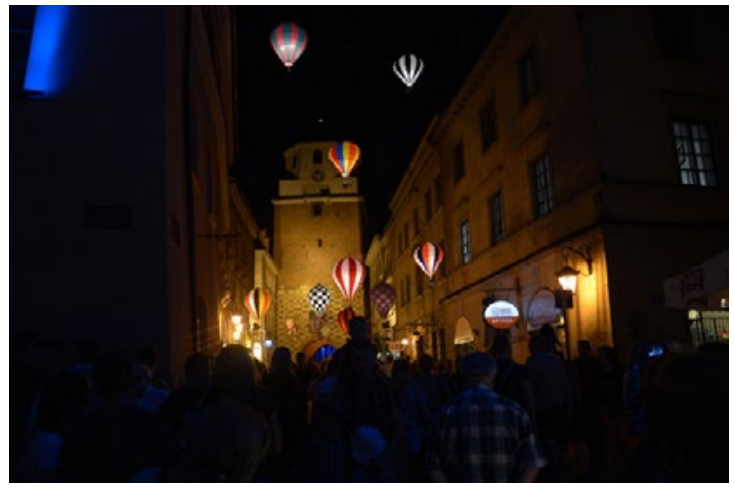

Fig. 7. Cultural night in Lublin 2017, author's photo Noc Kultury Lublin 2017, fot. autora

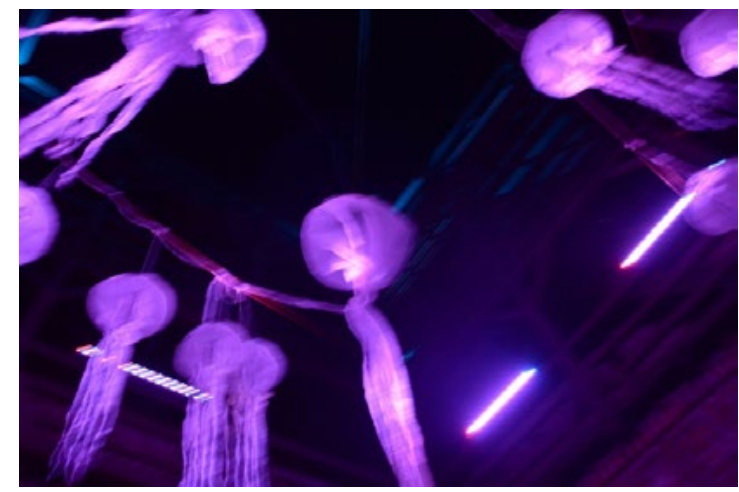

Fig. 8. Cultural night in Lublin 2018, author's photo Noc Kultury Lublin 2018, fot. autora

Social art associating citizens may concern different areas of artistic creativity and take place in different fields of social and civic activity. The city of Lublin may serve as a good example for social gatherings in public space. The creative activities of the city authorities undertaken in recent years are conducive to social integration and are implemented through cyclical organisation of cultural and entertainment events taking place in

\footnotetext{
13 Op. cit., J. Gehl, Miasta dla ludzi,...s.178-179

14 I. Kabakow, Projekt publiczny albo duch miejsca, w: E. Rewers (red.), Miasto w sztuce - sztuka miasta, Kraków 2010, Universitas, s.347

15 J. Tichner, Etyka solidności, Wydawnictwo Znak, Kraków 1981, s. 42-44
} 
the city space. During the Carnaval Sztukmistrzów (the Carnival of the Artsmakers) or the Night of Culture, the public space of peaceful urban life changes into an illuminated boulevard of urban art, arousing the admiration of passers-by. (Fig. 7,8) Beautifully landscaped spaces that promote art with precisely designed details, provide many positive experiences that bring together, as well as integrate, and assimilate the community.

A given piece of art is not always accepted by the audience, but it always evokes emotions and remains in the memory of the recipient for a long time. An example is the Orbit Tower, created by artist Anish Kapoor and engineer-architect Cecil Balmond in London. The one hundred and eighteen-metre-high construction, consisting of a steel tower twisted into strange shapes, compared by many to the tower of Babel or Eiffel, was criticised for almost everything. With time, social resistance turned into acceptance and a kind of social pride in such a unique public art object, which became characteristic of London.

Since the 1980s, public art has also found an area for itself to counteract the visual monotony and vagueness, and to improve the aesthetic quality of stations, airports, underground networks, and railways. (Fig. 9) Thanks to this, public places stop being soulless and associated only with modern architecture or the existing order, and they become more open to people and foster social bonds. Elements of art in public space give visual identity to places that are not defined or monotonous, sometimes too ordered. They often aesthetize and make social life more attractive, at the same time satisfying the need of people to interact with beauty.

The presentation of art in public space is based on the links between the institutional world of art and public space and is more and more often presented outside the walls of the gallery. Art collections presented in squares and streets, courtyards, backyards or buildings are often a prelude, an invitation to an exhibition or other cultural event, presenting the motifs that are present in particular urban space. (Fig. 10) Art, to a large extent, feeds the perspective of globality and localness in cities, representing a symbolic and cultural surplus of the landscape.

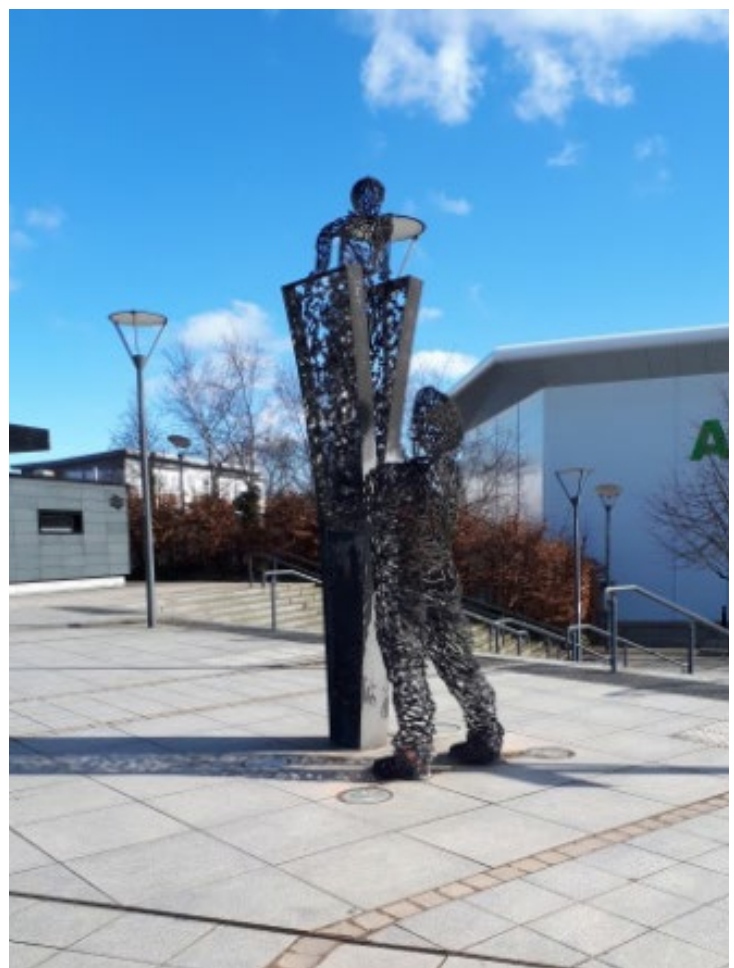

Fig. 9. A steel sculpture located next to the railway station in Alloa, Scotland, 2018, author's photo

Stalowa rzeźba znajdująca się przy jednej ze stacji klejowej w Alloa w Szkocji 2018, fot. autora

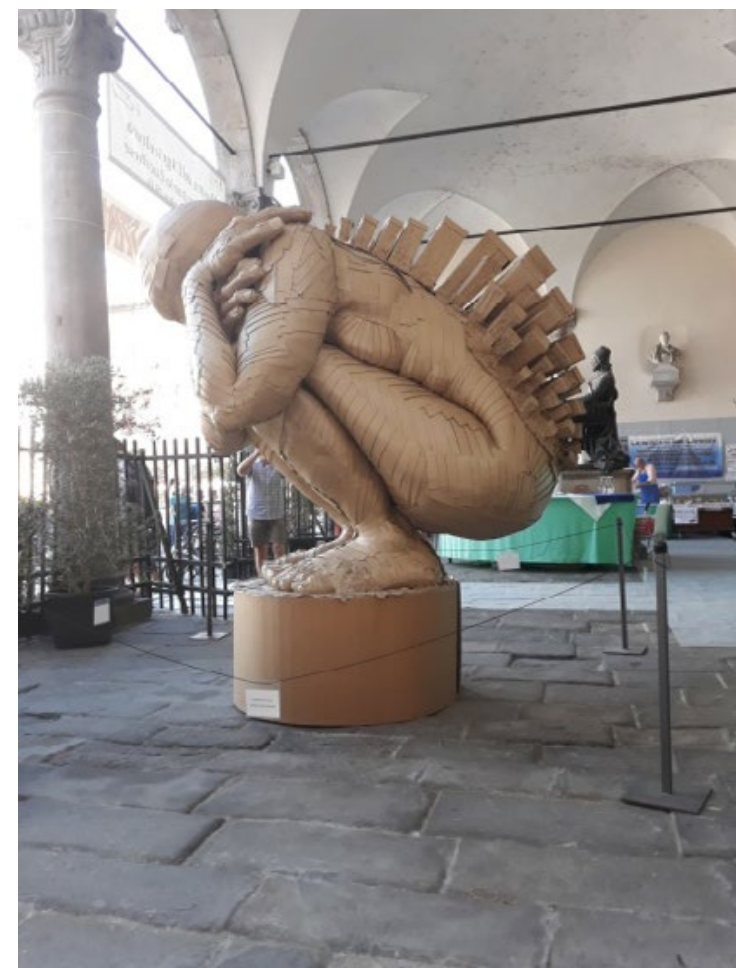

Fig. 10. Paper sculpture in the urban space, which previewed exhibition in one of the gallerie, Florence 2018, photo Katarzyna Kielin

Rzeźba z papieru w przestrzeni miejskiej stanowiąca zapowiedź wystawy w jednej z galerii, Florencja 2018, fot. Katarzyna Kielin 
A public space is an area where actions are aimed at building understanding between its users "(...) is a place that belongs to everyone and an area where non-violent discussion is possible, where in the public sphere, the legitimacy of disputes over socially important and unimportant matters can still be recognised." ${ }^{\prime 16}$

Both consensual and agonistic visions of the public sphere treat public space as one of its dimensions, which implies that it is governed by different laws than private space. We can also distinguish many semi-public spaces, such as backyards, playgrounds, housing estate interiors or even the facades of buildings that belong to private owners or housing communities. Introducing elements of art into such spaces, brings together and assimilates the community living there, who often use it as an element of discussion. More and more often closed backyards are also becoming a space for artistic activities, which leads to the change of their status into a more open, "friendly" and socially acceptable form. (Fig. 11)

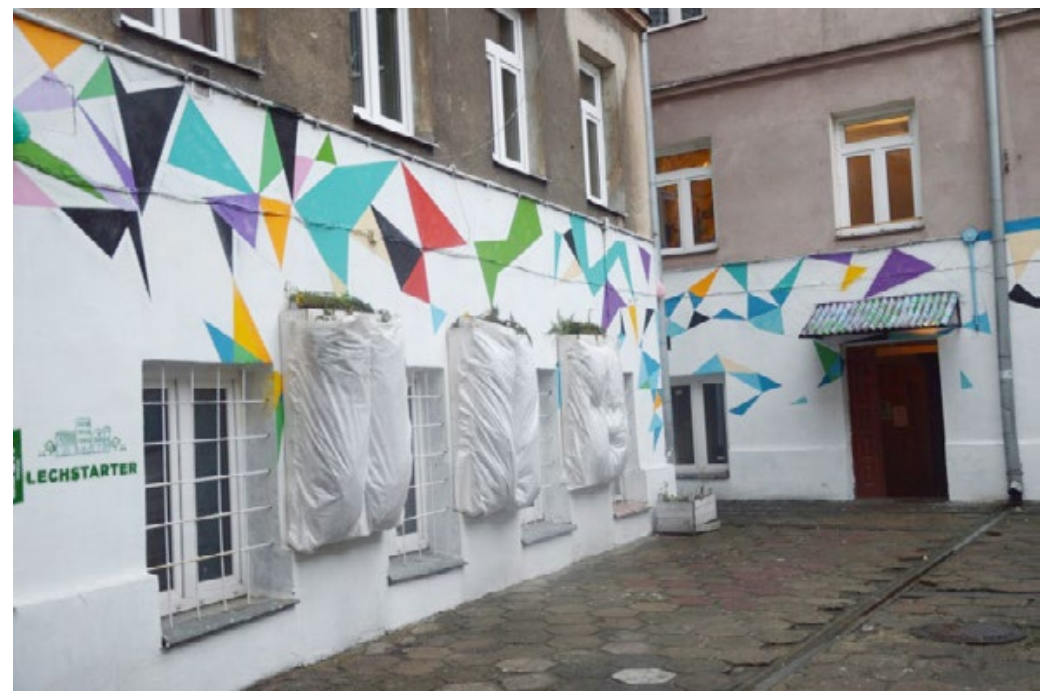

Fig. 11. The backyard located in one of the gates on Lubartowska street in Lublin, 2017, author's photo

Podwórko znajdujące się w jednej z bram przy ul. Lubartowskiej w Lublinie, 2017, fot. autora

Urban space is not a public space if it is not socially used, and its status is never permanently defined or specified. Jeb Brugman, describing the phenomenon of Barcelona, presented it as a city that could serve as a model for others due to the intensity of social life in common (urban) spaces. In recent years, the boundary between what is public in art and what is excluded from general use, has shifted dynamically.

Art as a public space fulfils a specific function, providing a shade or resting place, offering some kind of relaxation. Thus, it initiates physical and bodily interaction with the recipient, which constitutes its public character. Thanks to people, it becomes more "accessible" and does not lose its public character, serving man and becoming "art in public space".

Art as a public space has one more important application that directly refers to the social and civic functions of art. It is the creation of "social" spaces, conducive not only to interaction with art, but also to interaction with other people in this space.

At present, the designers who manage empty urban squares with greenery, benches or sculptures, create places conducive to "being with each other", whose public nature is connected with the function of socializing the recipients. They unite people in a physical and symbolic way, creating modern agora, accessible to all citizens. ${ }^{17}$ Works of art placed in urban space create a friendly environment in which people communicate and take joint actions for social use.

Art provides an opportunity for dialogue and balanced communication between different social groups. It influences the social structure, going in the direction of changing the rules of social exclusivity and inclusion. Thus, dialogue in art serves to establish intercultural contacts in the society, which are treated as an important 
remedy for the persisting phenomena of [...] stereotyping, racism, xenophobia, intolerance and discrimination. Contemporary artists more and more often turn out to be the sender of a committed message in favour of creating a communication situation in which the audience would be involved. Seeing in art the unexploited possibility of communication not so much with the recipients as between them, the artists create participatory, interactive projects based on dialogue and cooperation. They are focused on creating a context conducive to communication, aimed at solving non-artistic problems. ${ }^{18}$

Every kind of art, not only has the right, but in a way, also the obligation to penetrate new areas and cross borders. A 2010 study on the social impact of art in public space shows that people taking part in artistic projects (e.g. Paweł Althamer's "Rubber" 2010) rooted in the city space, trust the artist much more than they trust city authorities, architects, or non-governmental organizations. The persons surveyed noticed the enormous potential of art, considering that artists should be the first to "diagnose" urban space and intervene in it. At the same time, they emphasized that it is art that should lead to social discussions, taking the viewer to another level of understanding. ${ }^{19}$

Art in urban space often gives a given place a new value, and increases the capital of the city by removing the unfavourable opinion about it. Many artistic projects carried out in potentially attractive districts of the city, lead to the improvement of their quality and strengthening of neighbourhood ties. Paweł Althamer's project "Common Concern" can serve as an example here. (2010), which resulted in the renovation of a staircase in a block of flats at 13 Krasnobrodzka Street in Warsaw's Bródno, carried out together with its residents. A neglected staircase transformed into a spacecraft as a result of a discussion between tenants, which resulted in strengthening neighborhood ties. The renovation was preceded by a series of other actions, which effectively promoted the implementation of the project. Intervention in a common public space has a positive effect if it is part of a long-term process based on local community cooperation. ${ }^{20}$

All creative activities make the inhabitants aware that it is worth creating art in order to improve social conditions of living. Placing elements of art in open public spaces is meant to convince people that both the artist and every inhabitant can influence the appearance, infrastructure and character of the place where they live. ${ }^{21}$ The priority is therefore to work together with the local community of the artist placing his works in a space accessible to all residents. Their main aim is not only to work with people, but to draw attention to an important social topic that contributes to the social exchange of views.

The socially important issues that are often raised in the works of artists are attractive topics that lead to bigger involvement of people. Art dealing with socially important issues does not in itself lead to a solution of the problem, but calls for a discourse that contributes to its solution. It turns out, however, that artistic projects which strongly interfere with the area used by a given community and revitalize it, are very few in number.

By raising socially relevant topics, which often continue in a complex public debates or other forms, they contribute to broadening social ties and exchanging of views. Concern for the continuation of socially important projects should become the duty not only of artists, but especially of the whole society, which contributes to their creation. Otherwise, the artists' right to enter squares, streets, estates, and backyards that are inhabited by people who are allowed to refuse their use as the material for art, could be challenged.

\section{Conclusions}

Art in urban space takes on various forms. On the one hand it creates "street art" in the form of multi-format murals, sculptures or monuments, and on the other hand it presents full-size installations that enliven the "urban tissue". For many people, art brings peace and serenity, teaches openness to others and their needs, ensuring their satisfaction with everyday life. At present, elements of art in urban space can be found in many

\footnotetext{
18 A. Sadowski, Uwarunkowania dialogu międzykulturowego na pograniczach „Pogranicze. Studia społeczne”, nr 21, 2013, s. 89-105 (s. 94)

19 J. Erbel, K. Herbst, Sztuka w przestrzeni publicznej. Raport z badania, w: Liberated Energy, J. Baranowska, P. Sztarbowski (red.), Instytut Teatralny im. Zbigniewa Raszyńskiego, Warszawa 2011, s. 154-171

20 M. Iwański, R. Jakubowicz, Rewitalizacja czy gentryfikacja poznańskiego Chwaliszewa, „Przegląd Anarchistyczny”, nr 12, 2011, s. 257

21 "O projekcie", http://lipowa.org/, [data dostępu: 28.08.2011.]
} 
cities in Poland or abroad, where they constitute an excellent form of social understanding, which contributes to the deepening of social ties.

Analyzing the examples presented above, it is possible to draw important conclusions concerning the use of art as a tool of social inclusion. The exhibition of art itself strengthens the sense of exclusion and alienation, especially when it is incomprehensible to the viewer. Action for social inclusion through art requires an indepth recognition of the social context and should take place with the participation of the given social group with which it is associated. Art serving social inclusion should create situations of communication and dialogue over existing social divisions, be subjective and creative, and the effects of its actions should be made public.

Creative activity is a strong argument for integrating and socialising an individual person into society. Man, being a social being, cannot live in loneliness and art allows him to fill this space by being an open form of expression. It enables a person to belong to a given community, teaching him or her of the understanding of others and allowing them to experience the world with all the senses available. Active participation in cultural events creates an opportunity for inclusion into a given social environment, stimulates imagination, develops sensual and tactile sensitivity, and promotes creative development, becoming an excellent form of social existence. The reception of a work of art with the participation of other people expands the scope of personal activities and respect for others.

Art is a very important tool for dialogue with reality, creating an opportunity to express what is hidden in everyday life. This kind of creative activity has a basic task to stimulate the viewers to reflection by touching upon issues related to tolerance, equality, corporeality or the place of a human being in society. A type of creative activity devoted to social problems in psychological, existential or aesthetic contexts, is a very important issue in the process of socialisation and better interpersonal communication.

Art in the city space creates a platform for a better understanding of human needs and functioning in the public sphere. Despite many years of research and observation, the question of the importance of art in human life and functioning is still not fully explored. However, it is crucial to state that it plays an important role in the socialization process, regardless of the place in which it is located.

\section{Bibliography}

[1] Chmielewski J. M., Teoria urbanistyki w projektowaniu i planowaniu miasta. Oficyna Wydawnicza Politechniki Warszawskiej, Warszawa 2001, s. 51-53.

[2] Drozd G., Obudzić śpiąca bestię, "Miejsca transformacji”, "Krytyka Polityczna” 27-28/2011, s. 58.

[3] Erbel J., Herbst K., Sztuka w przestrzeni publicznej. Raport z badania, w: Liberated Energy, J. Baranowska, P. Sztarbowski (red.), Instytut Teatralny im. Zbigniewa Raszyńskiego, Warszawa 2011, s. 154-171.

[4] Franczak K., Demokratyczny potencjat sztuki w przestrzeni miejskiej, w: O miejskiej sferze publicznej. Obywatelskość i konflikty o przestrzeń, M. Nowak, P. Pluciński (red.), korporacja ha!art, Kraków 2011, s. 260-261.

[5] Gehl J., Miasta dla ludzi, Wydawnictwo RAM 2014, s. 178-179.

[6] Golka M., Socjologiczny obraz sztuki, Poznań 1996, Ars Nova, s.190-197.

[7] Iwański M., Jakubowicz R., Rewitalizacja czy gentryfikacja poznańskiego Chwaliszewa, „Przegląd Anarchistyczny”, nr 12, 2011, s. 257.

[8] Kabakow I., Projekt publiczny albo duch miejsca, w: E. Rewers (red.), Miasto w sztuce - sztuka miasta, Kraków 2010, Universitas, s.347.

[9] Krause K. Ch., Public art: Theory, practice and populism, Malden, Oxford, Carlton 2008, Blackwell Publishing.

[10] Miwon K., Sztuka publiczna w przestrzeni: integracja czy interwencja, "Kultura Współczesna”, nr 4, 2009, s. $103-131$.

[11] Nawratek K .., Miasto jako idea polityczna, korporacja ha!art, Kraków 2008, s. 74.

[12] Ossowski S., Wybór pism estetycznych, wprow., wyb. i oprac. Bohdan Dziemidok, Kraków2004, Universitas, s. 116.

[13] Read H., Wychowanie przez sztukę., J. Bielecki, Osobowość młodzieży niepetnosprawnej z zaburzeniami wzroku, stuchu, ruchu i mowy. Pallotinum, Warszawa 1990, s. 178-182.

[14] Rykwert J., Pokusa miejsca. Przeszłość i przyszłość miast, Kraków 2013.

[15] Sadowski A., Uwarunkowania dialogu międzykulturowego na pograniczach, „Pogranicze. Studia spoteczne”, nr 21, 2013,s. 89-105(s.94).

[16] Szreder K., Sztuka publiczności, „Res Publica Nowa”, nr 4, 2008, s. 42-51. 
[17] Taborska H., Wspótczesna sztuka publiczna. Dzieła i problemy, Wiedza i Życie, Warszawa 1996.

[18] Tichner J., Etyka solidności, Wydawnictwo Znak, Kraków 1981, s. 42-44.

[19] Wojnar I., Teoria wychowania estetycznego - zarys problematyki. Państwowe Wydawnictwo Naukowe, Warszawa 1980, s. 12.

[20] Zabłocki J., Integracja szansą wychowania nowego pokolenia. Wydawnictwo Naukowe NOVUM, Płock 2002, s. 76.

[21] https://pl.wikipedia.org/wiki/Integracja_spo\%C5\%82eczna. [dostęp: 19.12. 2016].

[22] "O projekcie", http://lipowa.org/ , [data dostępu: 28.08.2011].

[23] http://gazetadom.pl/nieruchomosci/1,102725,8464877,Artysci_zmieniaja_jedno_z_najgorszych_osieli_w_stolicy.html, [data dostępu 07.07.2011]. 